\title{
Introduction to part I
}

\author{
Carlisle George \\ Senior Lecturer \\ School of Computing Science \\ Middlesex University London \\ c.george@mdx.ac.uk
}

The celebration of the professional life and work of Professor Jacques Berleur is in some way also a celebration of the many advances that have been made in information and communication technologies (ICTs). These advances have resulted in what we commonly call the Information Society, due to the pervasive nature of ICT in our everyday lives. An important aspect of Professor Berleur's work has been his contribution to raising awareness of social and ethical issues related to the Information Society. One such issue is the impact of ICT on democracy which is the focus of the three papers in this chapter by Professor Deborah Johnson, Stefano Rodotà, and Professor Klaus Brunnstein respectively.

ICT and the technical infrastructure of computer networks have issued in a 'new' type of democracy which has associated social, political and cultural dimensions. The networked society facilitates what Stefano Rodota calls a 'continuous' democracy. Here all aspects of citizens' participation in the networked society (e.g. meeting, accessing, consulting, chatting, protesting) can occur continuously. Professor Johnson sees this reinvention of democracy in the wider context of a global world, where ICT is an infrastructure linking interdependent individuals within nations and across nations. While one may argue that this 'new' democracy has been shaped by the availability of new technology, it is worthwhile to note here that Professor Johnson is quick to dispel the notion of technological determinism. She argues that technology is not autonomous, that while technology changes society, social forces also change technology (for example ICT designed to embody democratic values).

It is important to note that the very technology that enables participative and continuous democracy can invariably affect the quality of the democracy that it facilitates. Stefano Radata, warns that electronic technologies have their drawbacks in that they are often used for the surveillance and control of societies (e.g. for counter-terrorism, tagging, tracking) hence negating the very essence of democratic principles especially individual autonomy. Professor Johnson draws attention to the fact that technology is not neutral and relationships between technology and systems of authority usually exist. Hence technology can be used to impose social bias and other agendas. Finally, Professor Brunnstein, highlights some drawbacks of

Please use the following format when citing this chapter:

George, C., 2007, in Ifll' International lederation for Information Processing. Volume 233, The Information Society: Innovations, l.cgitimacy, lathics and Democracy, eds. P. Croujon, I avelle, S., Duquenoy, P., Kimppa, K., I aurent, V., (Boston: Springcr), pp. $3-4$. 
technology, noting that the information society has inherent risks associated with software/hardware failure and misuse. Such failures may mean that the full potential of the technology is not realized, hence affecting the quality of the democracy that it is intended to facilitate.

The education of IT experts and citizens/ users in the information society is seen as critical to maintaining the 'new' ICT democracy. Professor Johnson argues that ICT is 'sociotechnical' consisting of hardware and software as well as a combination of artifacts, social practices, social relationships and institutions. She further argues that ICT professionals need to be educated to understand the significance of their work, in terms of its wider social, political, economic and cultural impact. In lamenting the systemic failures in ICT and the associated risks to society Professor Brunstein also calls for the education of IT professionals to enable them to enhance the quality of programs and testing; and to develop safer and secure designs, thereby reducing IT risks. With regard to citizens/users, Professor Johnson sees the need to educate citizens to enable them to participate in technological decision making, by understanding how technological choices are intertwined with social, political and cultural choices. Professor Brunstein, argues that the complexity of present IT systems, poor design and inadequate documentation may mean that users are not able to understand how to use such systems, leading to risky 'trial and error' attempts.

He further argues that users are 'slaves' to technologies that they are unable to master and control, therefore educating users is critical in the information age. Technology and democracy are inextricably linked. Technology impacts on democracy (for example facilitating 'continuous' communication and participation), however, our democratic values can also impact on technology (through the design of technology). This realization enables a society to gain better control over its destiny. It empowers citizens to question and effect technological change when necessary rather than become subject to the notion that technology autonomously determines social phenomena. The three papers in this chapter, while acknowledging the impact of ICT on democracy, also strongly assert that social forces/values impact on ICT in order to influence the growth of social institutions (like democracy). This thesis is one that Professor Jacques Berleur will readily concur with, especially since some of his work, (for example, in the area of social informatics) has specifically focused on how social forces and practices influence the social organization of information technologies. 